\title{
Larangan Menggandakan Dokumen Jabatan Pejabat Pembuat Akta Tanah (PPAT) Bagi Calon PPAT yang Menjalani Magang
}

\section{Anak Agung Ngurah Ari Dwiatmika ${ }^{1}$}

${ }^{1}$ Program Studi Magister (S2) Kenotariatan Fakultas Hukum Universitas Udayana, BaliIndonesia, E-mail: aridwiatmika94@gmail.com

\begin{tabular}{l}
\hline Info Artikel \\
\hline Masuk: 28 Maret 2019 \\
Diterima: 22 April 2019 \\
Terbit: 30 April 2019 \\
Keywords : \\
Land Deed Official's documents; \\
Land Deed Official candidates \\
who undergo an internship; \\
Copying; Without permission
\end{tabular}

Kata kunci:

Dokumen pelaksanaan jabatan Pejabat Pembuat Akta Tanah; Calon Pejabat Pembuat Akta Tanah yang menjalani magang; Menggandakan; Tanpa izin

Corresponding Author: Anak Agung Ngurah Ari Dwiatmika, E-mail: aridwiatmika94@gmail.com

\begin{abstract}
Land Deed Official (LDO) candidates who undergo an internship are prohibited from copying LDO's documents in accordance with Article 9 paragraph (3) Regulations of the State Minister of Agrarian Affairs number 10 of 2017, but the arrangement is unclear because it is not specified only applies from copying documents without permission or also applies against copying document with permission. The obscurity of the rule raises doubt for LDO candidates who undergo an internship to assist when asked for assist by LDO to copy LDO's documents to be used as supplementary files for deed registration. The problems discussed in this research are how the scope of the LDO's documents are prohibited from being copied by the LDO candidates who undergo an internship and whether copying the LDO's documents at the LDO's request carried out the infringement of law. The purposes of the study are to find out the scope of the documents that banned to copy and to find out copying the $L D O$ 's documents at the LDO's request is an infringement or not. The research used normative legal research method. The conclusion are the scope of the LDO's documents which is prohibited from being copied includes the paper based documents and electronic documents used by LDO to carry out his position, as well as the draft deeds and draft letters which have not been signed. Copying the LDO's documents based on the request of the LDO or with permission from the LDO for office needs is not an infringement.
\end{abstract}

\footnotetext{
Abstrak

Calon Pejabat Pembuat Akta Tanah (PPAT) yang menjalani magang dilarang menggandakan dokumen pelaksanaan jabatan PPAT sesuai Pasal 9 ayat (3) Permen Agraria dan Tata Ruang/Kepala Badan Pertanahan Nasional Nomor 10 Tahun 2017, namun pengaturan pada pasal tersebut tidak jelas karena tidak ditentukan larangan tersebut hanya berlaku terhadap penggandaan dokumen tanpa izin dari PРAT atau berlaku juga terhadap penggandaan dokumen atas izin PPAT. Ketidakjelasan aturan tersebut menimbulkan keragu-raguan bagi calon PPAT yang menjalani magang untuk membantu ketika dimintai bantuan oleh PPAT untuk menggandakan atau memfotokopi dokumen jabatan PPAT untuk digunakan sebagai berkas pelengkap pendaftaran akta. Permasalahan yang diteliti adalah
} 
DOI :

10.24843/AC.2019.v04.i01.p05

\section{Pendahuluan}

Tanah merupakan Sumber Daya Alam karunia Tuhan sebagai tempat manusia mejalani kehidupan. Tanah berfungsi sebagai tempat manusia mendirikan rumah, tempat mananam tanaman pangan, dan tempat menjalani mata pencaharian atau kegiatan usaha. Pentingnya tanah bagi manusia membuat semua orang ingin memiliki tanah. Cara untuk memperoleh hak atas tanah adalah dengan membeli, mewaris, menerima hibah, menyewa, memohon pemberian hak atas tanah dari negara, atau membuat perjanjian pemberian hak guna bangunan atau hak pakai atas tanah hak milik. Cara yang paling lumrah digunakan untuk mendapatkan hak atas tanah adalah melalui tindakan membeli tanah dengan membuat akta jual beli di kantor Pejabat Pembuat Akta Tanah (PPAT).

PPAT merupakan mitra masyarakat dan pemerintah dalam bidang pendaftaran tanah terutama berperan dalam membuat akta dan mendaftarkan akta agar menjamin kepastian kedudukan seseorang sebagai subjek hak atas tanah. ${ }^{1}$ PPAT diberikan status sebagai pejabat umum yang berwenang membuat akta otentik yang obyeknya hak atas tanah dan hak milik atas satuan rumah susun. Pejabat umum dalam hal ini berarti orang yang dilantik oleh pemerintah dengan diberi kedudukan dan kewenangan tertentu untuk menjalankan tugas melayani masyarakat umum pada bidang yang telah ditentukan. ${ }^{2}$ Para pemangku jabatan PPAT diangkat oleh Menteri Agraria dan Tata Ruang dan diberikan tugas melayani masyarakat dalam membuat akta yang berisi perbuatan hukum terhadap hak atas tanah atau satuan rumah susun. Akta yang dibuat oleh PPAT merupakan akta otentik, yaitu akta yang dibuat oleh pejabat umum yang berwenang dengan tujuan akan digunakan sebagai alat bukti mengenai

\footnotetext{
1 Swandewi, N. L. P., Murni, R. A. R., \& Dharmawan, N. K. S. (2016). Penggunaan Blanko Akta Pejabat Pembuat Akta Tanah Dengan Diterbitkannya Peraturan Kepala Badan Pertanahan Nasional Nomor 8 Tahun 2012. Acta Comitas, 1, 42-51, h. 43.

2 Salim HS. (2016). Teknik Pembuatan Akta Pejabat Pembuat Akta Tanah (PPAT). Jakarta: Rajawali

Pers, h. 87.
} 
perbuatan hukum tertentu. ${ }^{3}$ Akta tersebut berfungsi sebagai alat bukti yang dijadikan dasar pendaftaran berubahnya data pertanahan, misalnya pada jual beli tanah perlu dilakukan pendaftaran untuk menjamin kepastian hukum status kepemilikan tanah telah beralih dari penjual kepada pembeli sehingga transaksi jual beli tanah tersebut perlu didaftarkan pada kantor pertanahan. Berdasarkan Pasal 37 ayat (1) Peraturan Pemerintah Nomor 24 Tahun 1997 tentang Pendaftaran Tanah (selanjutnya disingkat PP 24/1997), pendaftaran mengenai bergantinya pemilik tanah hanya dapat dilakukan dengan melampirkan akta PPAT.

Menanggapi pentingnya peran PPAT dalam proses pendaftaran tanah dan agar diperoleh individu yang kompeten untuk menjalankan tugas PPAT, dibuatlah regulasi mengenai syarat-syarat untuk dapat diangkat sebagai PPAT. Syarat-syarat tersebut ditentukan secara limitatif pada Pasal 6 Peraturan Pemerintah Nomor 24 Tahun 2016 tentang Perubahan Atas Peraturan Pemerintah Nomor 37 Tahun 1998 tentang Peraturan Jabatan Pejabat Pembuat Akta Tanah (selanjutnya disingkat Peraturan Jabatan PPAT), beberapa diantaranya adalah tidak pernah dipenjara karena melakukan tindak pidana yang diancam hukuman lima tahun penjara atau lebih berat, telah lulus sarjana hukum dan magister kenotariatan atau pendidikan khusus PPAT, lulus ujian pengangkatan PPAT, dan telah magang atau bekerja pada kantor PPAT selama satu tahun setelah lulus magister kenotariatan. Khusus mengenai syarat harus menjalani magang setelah lulus magister kenotariatan merupakan regulasi baru yang berlaku mulai tahun 2016. Kegiatan magang berguna untuk membentuk calon-calon PPAT yang profesional.

Kegiatan magang tidak diwajibkan bagi pihak yang lulus dari program pendidikan khusus PPAT, sedangkan bagi lulusan magister kenotariatan yang hendak menjadi PPAT, magang merupakan suatu kewajiban agar bisa mengikuti ujian pengangkatan PPAT. Kewajiban menjalani magang dapat diganti dengan bekerja sebagai pegawai di kantor PPAT dan kantor pertanahan. Jadi, bagi pihak yang lulus dari magister kenotariatan diberikan dua pilihan antara menjalani magang atau bekerja di kantor PPAT dan kantor pertanahan. Durasi waktu dalam melaksanakan magang dan bekerja di kantor PPAT dan kantor pertanahan sama-sama dilaksanakan dalam waktu minimal satu tahun dan sama-sama harus dilakukan setelah lulus magister kenotariatan. Perbedaannya hanyalah pada saat magang, peserta magang membantu operasional kantor PPAT dan kantor pertanahan dengan sukarela tanpa menuntut imbalan, sedangkan bagi pihak yang bekerja di kantor PPAT dan kantor pertanahan berhak memperoleh gaji sesuai perjanjian kerja.

Berdasarkan Pasal 7 ayat (2) Peraturan Menteri Agraria dan Tata Ruang/Kepala Badan Pertanahan Nasional Nomor 10 Tahun 2017 tentang Tata Cara Ujian, Magang, Pengangkatan dan Perpanjangan Masa Jabatan Pejabat Pembuat Akta Tanah (selanjutnya disingkat Permen ATR/BPN 10/2017), magang dilaksanakan selama enam bulan di kantor pertanahan dan enam bulan lagi di kantor PPAT. Tidak sembarang kantor PPAT dapat dijadikan tempat magang. Kriteria kantor PPAT yang cocok dijadikan tempat magang ditentukan dalam Pasal 8 ayat (2) Permen ATR/BPN 10/2017, yaitu pada kantor PPAT yang telah menjabat minimal selama lima tahun atau

3 Yunarko, B. (2013). Kedudukan Jabatan dan Akta Pejabat Pembuat Akta Tanah dalam Sengketa di Peradilan Tata Usaha Negara. Perspektif, 18(3), 188-194, h. 193. 
pada kantor PPAT yang telah membuat minimal 60 (enam puluh) akta PPAT dalam karirnya. Ketentuan tersebut bertujuan agar calon PPAT yang menjalani magang dapat belajar dari PPAT yang sudah berpengalaman sehingga dapat memetik banyak pelajaran mengenai berbagai macam praktek dunia PPAT.

Pihak yang ingin melaksanakan magang harus mengajukan surat permohonan magang secara tertulis kepada Kepala Kantor Pertanahan dan PPAT. Surat permohonan magang yang diajukan kepada PPAT dikirim pula tembusannya kepada Ketua Pengurus Daerah Ikatan Pejabat Pembuat Akta Tanah (IPPAT) yang berkedudukan di daerah setempat. Surat permohonan magang harus disertai dengan beberapa dokumen yang ditentukan Pasal 7 ayat (5) Permen ATR/BPN 10/2017, yaitu fotokopi Kartu Tanda Penduduk, fotokopi ijazah magister kenotariatan atau pendidikan spesialis notaris, surat pernyataan bersedia menjalani magang secara cuma-cuma tanpa diberi imbalan, dan bagi pihak yang telah lulus ujian PPAT wajib melampirkan surat keterangan lulus ujian PPAT.

Berdasarkan Pasal 9 ayat (1) dan ayat (2) Permen ATR/BPN 10/2017, peserta magang wajib membantu kegiatan operasional di kantor pertanahan dan kantor PPAT. Melalui praktek secara langsung diharapkan peserta magang dapat memahami proses pendaftaran tanah yang merupakan tugas pokok PPAT. Pada saat magang di kantor pertanahan, peserta magang wajib membantu proses pelayanan pertanahan, pemeriksaan akta PPAT yang didaftar, dan pemeriksaan data yuridis permohonan hak atas tanah. Ikut membantu memeriksa akta PPAT yang didaftarkan pada kantor pertanahan berguna bagi calon-calon PPAT agar mengetahui jenis-jenis kesalahan yang terdapat pada akta PPAT sehingga dapat dipelajari dan dihindari. Berikutnya pada saat magang di kantor PPAT, peserta magang wajib membantu kegiatan PPAT dalam membuat akta perbuatan hukum terhadap hak atas tanah atau satuan rumah susun minimal tujuh buah akta dan wajib membantu mengelola protokol PPAT. Walaupun Pasal 9 ayat (2) huruf a Permen ATR/BPN 10/2017 hanya mewajibkan peserta magang membantu membuat tujuh akta, akan lebih baik jika peserta magang berpartisipasi membuat akta lebih dari tujuh akta dan berpartisipasi dalam membuat berbagai jenis akta karena terdapat delapan jenis akta PPAT dan teknik pembuatannya berbeda-beda.

Peserta magang yang telah melaksanakan magang selama enam bulan di kantor pertanahan dan enam bulan di kantor PPAT akan diberikan Surat Keterangan Magang dari kantor pertanahan dan PPAT. Surat keterangan magang nantinya digunakan oleh calon PPAT untuk mendaftar ujian pengangkatan PPAT secara online. Tanpa surat keterangan magang, calon PPAT akan dinyatakan tidak lulus seleksi administrasi.

Selama melaksanakan magang peserta magang wajib mentaati tata tertib yang berlaku di lokasi magang. Selain itu, aturan terpenting yang perlu diperhatikan adalah Pasal 9 ayat (3) Permen ATR/BPN 10/2017 yang menentukan bahwa "peserta magang wajib merahasiakan dan dilarang menggandakan dokumen pelaksanaan kegiatan dan pelayanan kantor pertanahan dan pelaksanaan jabatan PPAT". Kewajiban dan larangan tersebut wajib diperhatikan oleh peserta magang agar tidak terjerat perkara hukum, namun dalam peraturan tersebut tidak dijelaskan dokumen-dokumen apa saja yang termasuk dalam ruang lingkup dokumen pelaksanaan jabatan PPAT. Selain karena pada peraturan menteri tersebut tidak terdapat penjelasan, pada pasal- 
pasalnya juga tidak dijabarkan dokumen-dokumen apa saja yang dimaksud frasa "dokumen pelaksanaan jabatan PPAT" pada Pasal 9 ayat (3) Permen ATR/BPN $10 / 2017$.

Dokumen-dokumen kantor pertanahan yang tidak boleh digandakan sebagaimana dimaksud Pasal 9 ayat (3) Permen ATR/BPN 10/2017 dapat diketahui daftar rincinya pada lampiran Permen ATR/BPN 10/2017. Dokumen-dokumen tersebut dapat dilihat pada format Surat Pernyataan Magang yang berisi pernyataan bahwa peserta magang tidak akan menggandakan dokumen layanan pertanahan berupa daftar isian/daftar umum pendaftaran tanah (buku tanah, surat ukur, daftar nama dan daftar tanah) serta warkah penerbitan sertifikat dan pemeliharaan data pendaftaran tanah (peralihan hak dan pembebanan hak). Pada format surat pernyataan magang juga terdapat pernyataan bahwa perserta magang di kantor PPAT tidak akan menggandakan dokumen pelaksanaan jabatan PPAT dan protokol. Pernyataannya hanya demikian, tidak menjelaskan lebih rinci dokumen-dokumen yang termasuk ruang lingkup dokumen pelaksanaan jabatan PPAT.

Ketika magang di kantor PPAT, peserta magang dapat saja dimintai tolong oleh PPAT untuk memfotokopi kartu identitas diri penghadap yang nantinya akan digunakan untuk mendaftar peralihan hak atau pembebanan hak atas tanah atau satuan rumah susun di kantor pertanahan. Memfotokopi identitas diri penghadap sama artinya dengan menggandakan dokumen yang terdapat pada kantor PPAT. Penggandaan dokumen tersebut sering terjadi karena PPAT memang memerlukan fotokopi kartu identitas diri penghadap untuk digunakan mendaftarkan setiap akta yang dibuat PPAT mengenai peralihan hak ke kantor pertanahan sebagaimana diwajibkan oleh Pasal 113 ayat (2) huruf d dan huruf e Peraturan Menteri Negara Agraria/Kepala Badan Pertanahan Nasional Nomor 3 Tahun 1997 tentang Ketentuan Pelaksanaan Peraturan Pemerintah Nomor 24 Tahun 1997 tentang Pendaftaran Tanah (selanjutnya disingkat Permen Agraria 3/1997).

Membantu PPAT membuat akta merupakan kewajiban bagi peserta magang. Pada saat membantu membuat akta, peserta magang juga menggandakan dokumen yang terdapat di kantor PPAT. Pada saat dimintai tolong oleh PPAT untuk membuat akta, peserta magang akan menyalin (copy) draf akta PPAT yang terdapat pada komputer yang satu kemudian ditempel (paste) pada komputer yang lain sehingga muncul salinan draf akta PPAT tersebut. Salinan yang berupa dokumen elektronik tersebut kemudian diperbaiki dan disesuaikan dengan data penghadap dan data obyek perbuatan hukum yang akan dibuatkan akta. Tindakan menyalin draf akta PPAT yang ada di komputer juga termasuk tindakan menggandakan dokumen. Peserta magang menggandakan dokumen tersebut karena memang diperintahkan oleh PPAT atas kesadaran PPAT sendiri.

Pada Pasal 9 ayat (3) Permen ATR/BPN 10/2017 tidak dijelaskan tindakan peserta magang menggandakan dokumen pelaksanaan jabatan PPAT atas perintah PPAT merupakan pelanggaran atau tidak. Isi pasalnya hanya menentukan peserta magang dilarang menggandakan dokumen pelaksanaan jabatan PPAT, sehingga terdapat kekaburan norma mengenai ruang lingkup larangan tersebut. Apakah larangan tersebut hanya berlaku terhadap penggandaan dokumen yang dilakukan tanpa izin dari PPAT atau juga berlaku bagi perbuatan menggandakan dokumen atas izin atau 
perintah dari PPAT. Kekaburan norma tersebut mengakibatkan kesulitan memberlakukan aturan hukum secara tepat (legal indeterminacy). ${ }^{4}$

Berdasarkan uraian permasalahan tersebut maka penelitian ini mengangkat dua rumusan masalah, yaitu: Bagaimana ruang lingkup dokumen pelaksanaan jabatan PPAT yang dilarang digandakan oleh calon PPAT yang menjalani magang di kantor PPAT? Dan Apakah perbuatan menggandakan dokumen pelaksanaan jabatan PPAT yang dilakukan peserta magang atas permintaan dari PPAT termasuk perbuatan melanggar Pasal 9 ayat (3) Permen ATR/BPN 10/2017?

Ada dua tujuan yang hendak dicapai dengan disusunnya penelitian tentang permasalahan di atas. Tujuan pertama adalah untuk mengetahui ruang lingkup dokumen pelaksanaan jabatan PPAT yang dilarang digandakan oleh calon PPAT yang menjalani magang di kantor PPAT serta mengidentifikasi dokumen-dokumen tersebut. Tujuan kedua adalah untuk mengetahui perbuatan menggandakan dokumen pelaksanaan jabatan PPAT yang dilakukan peserta magang atas permintaan dari PPAT termasuk perbuatan melanggar Pasal 9 ayat (3) Permen ATR/BPN 10/2017 atau merupakan perbuatan yang sah menurut hukum.

Sebelum penelitian ini dilakukan, telah terdapat penelitian-penelitian terdahulu yang menganalisa mengenai kewajiban magang bagi calon notaris dan PPAT. Pertama, penelitian yang dilakuan oleh Fuja Hadi Saputra, Mahasiswa Magister Kenotariatan Universitas Gadjah Mada, dengan judul "Kewajiban Magang Calon Pejabat Pembuat Akta Tanah (PPAT) di Kantor Agraria dan Tata Ruang/Pertanahan Kota Yogyakarta". Penelitian tersebut membahas mengenai pelaksanaan magang bagi calon PPAT di kantor pertanahan Kota Yogyakarta dan kewajiban calon PPAT untuk merahasiakan dokumen serta sanksi yang dikenakan terhadap pelanggarannya. Penelitian ini berbeda dengan penelitian Fuja Hadi Saputra karena penelitian ini fokus pembahasannya mengenai larangan menggandakan dokumen pelaksanaan jabatan PPAT, sedangkan penelitian Fuja Hadi Saputra terfokus pada kewajiban merahasiakan dokumen kantor pertanahan serta sanksi atas perlanggarannya. Kedua, penelitian yang dilakukan oleh Rani Yuliani dengan judul "Tanggung Jawab Hukum Calon Notaris yang Sedang Magang Terhadap Kerahasiaan Akta". Penelitian tersebut membahas mengenai tanggung jawab calon notaris yang sedang magang terhadap kerahasiaan akta dan sanksinya jika tanggung jawab tersebut dilanggar. Penelitian ini berbeda dengan penelitian Rani Yuliani karena penelitian ini lebih fokus membahas tentang jabatan PPAT bukan notaris. Oleh karena itu, penelitian ini memiliki orisinalitas dan dapat memberi sumbangan baru bagi ilmu hukum.

\section{Metode Penelitian}

Penyusunan artikel ini beranjak dari kekaburan norma pada Pasal 9 ayat (3) Permen ATR/BPN 10/2017 yang mengakibatkan ketidakpastian dalam penerapannya. Ketidakpastian tersebut mengenai larangan menggandakan dokumen pelaksanaan jabatan PPAT. Apakah setiap tindakan menggandakan dokumen pelaksanaan jabatan PPAT merupakan perbuatan yang dilarang atau hanya perbuatan menggandakan

4 Nabila, S. (2015). Implikasi Yuridis Calon Notaris Magang Yang Tidak Melaksanakan Kewajibannya Sebagaimana Diatur Dalam Pasal 16 a Undang-undang Nomor 2 Tahun 2014 Tentang Jabatan Notaris. Kumpulan Jurnal Mahasiswa Fakultas Hukum, h. 5. 
tanpa izin PPAT saja yang dilarang. Permasalahan tersebut dikaji dengan menggunakan jenis penelitian hukum normatif karena kekaburan norma tersebut dicari penyelesaiannya dengan menganalisa peraturan hukum yang terkait. Ada tiga metode pendekatan yang digunakan, yaitu Pendekatan Frasa yang digunakan untuk mencari tahu ruang lingkup frasa dokumen pelaksanaan jabatan PPAT, Pendekatan Perundang-undangan diterapkan karena perlu dianalisis peraturan perundangundangan yang mengatur mengenai larangan menggandakan dokumen, dan Pendekatan Analisis Konsep Hukum digunakan untuk menganalisis konsep hukum yang berkaitan dengan rahasia jabatan PPAT. Bahan-bahan hukum yang digunakan menyusun artikel ini adalah PP 24/1997, Peraturan Jabatan PPAT, Permen Agraria 3/1997, dan Permen ATR/BPN 10/2017 sebagai bahan hukum primer. Digunakan juga bahan hukum sekunder berupa jurnal dan buku, serta bahan hukum tersier berupa kamus. Seluruh bahan hukum tersebut dikumpulkan menggunakan teknik sistem kartu selanjutnya dianalisis dengan teknik deskripsi, argumentasi, interpretasi, dan sistematisasi. Teknik interpretasi terutama digunakan untuk menafsirkan ruang lingkup frasa dokumen pelaksanaan jabatan PPAT. Teknik sistematisasi digunakan untuk menghubungkan peraturan-peraturan yang mengatur larangan menggandakan dokumen sehingga ditemukan jawaban mengenai permasalahan penelitian.

\section{Hasil dan Pembahasan}

\subsection{Ruang Lingkup Dokumen Pelaksanaan Jabatan PPAT yang Dilarang Digandakan Oleh Calon PPAT yang Menjalani Magang di Kantor PPAT \\ 3.1.1. Ruang Lingkup Dokumen Pelaksanaan Jabatan PPAT Mencakup Dokumen Fisik dan Dokumen Elektronik}

PPAT menjalankan jabatannya dengan membuat dokumen berupa akta, mendaftarkan akta dan dokumen-dokumen lainnya ke kantor pertanahan, serta menyimpan akta beserta dokumen pendukung akta. Akta yang dibuat PPAT memuat perbuatan hukum yang dilakukan orang lain. Isi akta tersebut wajib dirahasiakan oleh PPAT sesuai dengan sumpah yang telah diucapkan ketika dilantik sebagai PPAT. Kewajiban merahasiakan isi akta juga berlaku bagi calon PPAT yang sedang magang. Semua informasi mengenai akta dan dokumen-dokumen pelaksanaan jabatan PPAT serta dokumen-dokumen yang digunakan kantor pertanahan dalam memberi pelayanan kepada publik wajib dijaga kerahasiaannya oleh calon PPAT yang sedang magang di kantor PPAT dan Kantor Pertanahan. ${ }^{5}$ Selain wajib menjaga rahasia, calon PPAT juga dilarang menggandakan dokumen pelaksanaan jabatan PPAT sebagaimana ketentuan Pasal 9 ayat (3) Permen ATR/BPN 10/2017.

Dokumen apa yang termasuk ruang lingkup dokumen pelaksanaan jabatan PPAT tidak dijelaskan dalam Permen ATR/BPN 10/2017 sehingga perlu dilakukan penafsiran atau interpretasi. Interpretasi adalah suatu teknik yang memberikan penjelasan mengenai teks yang digunakan dalam peraturan hukum sehingga diketahui ruang lingkupnya dan dapat diterapkan secara pasti. Salah satu metode penafsiran adalah interpretasi gramatikal yaitu teknik mencari arti ketentuan hukum dengan berpedoman pada bahasa sehari-hari. ${ }^{6}$ Berdasarkan bahasa sehari-hari, makna

\footnotetext{
${ }^{5}$ Saputra, F. H. (2018). Kewajiban Magang Calon Pejabat Pembuat Akta Tanah (PPAT) di Kantor Agraria dan Tata Ruang/Pertanahan Kota Yogyakarta. Universitas Gadjah Mada, h. 1.

${ }^{6}$ Mertokusumo, S. (2009). Penemuan Hukum: Sebuah Pengantar. Yogyakarta: Liberty, h. 57.
} 
dokumen pelaksanaan jabatan PPAT adalah dokumen-dokumen yang digunakan PPAT untuk melaksanakan jabatannya sebagai PPAT. Sesuai Pasal 2 ayat (1) Peraturan Jabatan PPAT, tugas jabatan PPAT adalah melakukan sebagian kegiatan pendaftaran tanah dengan cara membuat akta. Selanjutnya PPAT bertugas mendaftarkan akta tersebut ke kantor pertanahan kabupaten/kota setempat sebagaimana ditentukan Pasal 40 PP 24/1997. Dokumen-dokumen yang didaftarkan adalah akta PPAT dan berkas-berkas yang diperlukan untuk kepentingan pendaftaran. Seluruh dokumen tersebut digunakan oleh PPAT untuk melaksanakan jabatannya sehingga termasuk dalam ruang lingkup dokumen yang tidak boleh digandakan oleh calon PPAT yang melaksanakan magang sebagaimana dimaksud Pasal 9 ayat (3) Permen ATR/BPN $10 / 2017$.

Protokol PPAT juga termasuk ruang lingkup dokumen pelaksanaan jabatan PPAT sebagaimana dimaksud Pasal 9 ayat (3) Permen ATR/BPN 10/2017 karena pada format Surat Pernyataan pada Lampiran Permen ATR/BPN 10/2017 terdapat pernyataan bahwa peserta magang tidak akan menggandakan protokol PPAT. Berdasarkan Pasal 1 angka 5 Peraturan Jabatan PPAT, protokol PPAT adalah dokumen yang disimpan oleh PPAT yang terdiri dari buku daftar akta, akta asli, warkah, arsip laporan, agenda dan surat-surat lain. Salinan akta bukan merupakan protokol PPAT karena salinan akta tidak disimpan oleh PPAT tetapi diberikan kepada pihak yang berkepentingan. Walaupun bukan merupakan protokol PPAT, salinan akta tidak boleh digandakan oleh calon PPAT yang sedang magang karena salinan akta termasuk sebagai dokumen pelaksanaan jabatan PPAT. Membuat salinan akta merupakan pelaksanaan jabatan PPAT untuk memberikan pelayanan bagi para pihak yang memerlukan salinan akta dan meminta agar dibuatkan. Jika berpegang teguh pada Pasal 21 ayat (3) huruf b Peraturan Jabatan PPAT maka PPAT hanya boleh memberikan salinan akta kepada pihak yang berkepentingan saja yaitu pihak-pihak yang melakukan perbuatan hukum dalam akta atau ahli warisnya, subjek hukum lain yang tidak berkepentingan tidak berhak meminta salinan akta. Berdasarkan alasan itu pula calon PPAT yang sedang magang tidak berhak meminta atau memperoleh salinan akta termasuk juga tidak boleh menggandakan salinan akta PPAT.

Pada kantor PPAT, selain terdapat dokumen fisik atau dokumen tercetak (paper based) berupa akta asli, salinan akta dan protokol, juga terdapat dokumen elektronik seperti draf surat-surat dan draf akta yang tersimpan pada media komputer. Pembuatan akta dengan komputer pertama kali dilakukan pada tahun 2013 ditandai dengan mulai berlakunya Peratuan Kepala Badan Pertanahan Nasional Nomor 8 Tahun 2012 tentang Perubahan Atas Peraturan Menteri Negara Agraria/Kepala Badan Pertanahan Nasional Nomor 3 Tahun 1997 tentang Ketentuan Pelaksanaan Peraturan Pemerintah Nomor 24 Tahun 1997 tentang Pendaftaran Tanah (selanjutnya disingkat Perka BPN 8/2012). Sebelum tahun 2013 PPAT membuat akta dengan cara mengisi blanko akta yang diperoleh dari BPN, setelah Perka BPN 8/2012 berlaku PPAT dapat menyiapkan dan membuat sendiri akta PPAT tanpa perlu mencari blanko akta ke kantor pertanahan.7 Pasal 96 ayat (1) Perka BPN 8/2012 mengatur penyiapan dan pembuatan akta oleh PPAT harus sesuai dengan bentuk dan cara pengisian yang ditentukan pada

\footnotetext{
7 Rismayanthi, I. A. W. (2016). Tanggung Jawab Pejabat Pembuat Akta Tanah (PPAT) terhadap Pendaftaran Peralihan Hak Atas Tanah yang Menjadi Objek Sengketa. Acta Comitas, 1, 77-93, h. 83.
} 
Lampiran Perka BPN 8/2012, tetapi tidak mengatur sarana yang harus digunakan untuk membuat akta, oleh karena itu PPAT dapat menggunakan komputer untuk membuat akta. Akta yang dibuat dengan komputer pada umumnya disimpan pada komputer sehingga di dalam komputer terdapat draf akta PPAT yang berbentuk dokumen elektronik.

Aktivitas manusia yang tidak bisa terlepas dari kecanggihan teknologi informasi mendorong pemerintah melakukan pembenahan hukum khususnya pengaturan mengenai penggunaan dan pemanfaatan teknologi informasi dalam pelayanan publik. ${ }^{8}$ Salah satu peraturan yang dikeluarkan oleh pemerintah dalam memanfaatkan teknologi informasi di sektor pertanahan adalah Peraturan Menteri Agraria dan Tata Ruang/Kepala Badan Pertanahan Nasional Nomor 5 Tahun 2017 tentang Layanan Informasi Pertanahan Secara Elektronik (selanjutnya disingkat Permen ATR/BPN 5/2017). Berdasarkan Pasal 4 Permen ATR/BPN 5/2017, PPAT harus melakukan pengecekan sertipikat menggunakan layanan informasi pertanahan secara elektronik sebelum melaksanakan pembuatan akta. Pengecekan sertipikat bertujuan untuk mencari tahu apakah tanah yang akan ditransaksikan bersih dari sengketa dan beban jaminan atau sedang menjadi objek sengketa dan sedang menjadi jaminan utang. ${ }^{9}$ Pengecekan sertipikat melalui sistem elektronik dilakukan dengan melampirkan identitas pemilik sertipikat, surat kuasa bahwa pemilik tanah memberi kuasa kepada PPAT untuk melakukan pengecekan, dan sertipikat asli yang semuanya harus dalam bentuk dokumen elektronik, oleh karenanya PPAT harus melakukan alih media terhadap dokumen-dokumen tersebut menjadi media elektronik. Metode yang dapat digunakan untuk melakukan alih media adalah scanning yaitu memindai dokumen tercetak dengan alat print scanner sehingga menghasilkan dokumen elektronik dalam format gambar yang dapat disimpan pada komputer. ${ }^{10}$

Dokumen-dokumen elektronik yang digunakan PPAT untuk mengajukan layanan informasi pertanahan secara elektronik merupakan dokumen-dokumen yang termasuk dalam ruang lingkup dokumen pelaksanaan jabatan PPAT sebagaimana dimaksud Pasal 9 ayat (3) Permen ART/BPN 10/2017 karena dokumen elektronik tersebut digunakan untuk melaksanakan jabatan PPAT yang salah satunya adalah mengecek sertipikat hak atas tanah. Dokumen elektronik lainnya yang terdapat pada kantor PPAT adalah draf akta PPAT dan draf surat-surat. Draf akta PPAT dan draf surat-surat yang tersimpan pada komputer PPAT merupakan dokumen-dokumen yang tidak dibubuhi tanda tangan. Dokumen yang diberi tanda tangan adalah draf akta dan draf surat-surat yang telah dicetak menjadi dokumen fisik dan telah dibacakan oleh PPAT di hadapan penghadap dan saksi-saksi. Akta dan surat-surat yang telah ditanda tangani tersebut digunakan oleh PPAT melaksanakan tugas jabatannya. Draf akta dan draf surat-surat dalam bentuk dokumen elektronik bukan merupakan protokol PPAT dan tidak perlu disimpan, namun draf akta dan draf surat-surat tersebut tetap saja disimpan oleh PPAT pada komputer sebagai data cadangan (back up) agar mudah

${ }^{8}$ Nurita, R. A. E. (2012). Cyber Notary: Pemahaman Awal dalam Konsep Pemikiran. Bandung: PT Refika Aditama, h. 39.

${ }^{9}$ Nurudin. (2016). Urgensi Penetapan Limitasi Waktu Pemeriksaan Kesesuaian Sertipikat Hak Atas Tanah di Kantor Pertanahan Sebelum Pembuatan Akta Oleh PPAT. Kumpulan Jurnal Mahasiswa Fakultas Hukum, h. 8.

${ }^{10}$ Rifauddin, M. (2016). Pengelolaan Arsip Elektronik Berbasis Teknologi. Khizanah Al-Hikmah Jurnal Ilmu Perpustakaan, Informasi, dan Kearsipan, 4(2), 168-178, h. 173. 
mencetak salinan akta tanpa perlu mengetik ulang akta jika dikemudian hari para pihak meminta dibuatkan salinan akta. Selain itu, draf akta dan draf surat-surat dapat pula digunakan sebagai pola (template) untuk membuat akta dan surat-surat yang baru dengan cara mengganti seperlunya uraian-uraian yang terdapat pada draf akta dan draf surat-surat disesuaikan dengan identitas klien yang baru dan identitas obyek perbuatan hukumnya. Walaupun draf akta dan draf surat-surat dalam bentuk dokumen elektronik tidak berisi tanda tangan dan bukan merupakan protokol PPAT, dokumen-dokumen tersebut juga termasuk dalam ruang lingkup dokumen pelaksanaan jabatan PPAT karena draf akta dan draf surat-surat tersebut merupakan hasil dari pelaksanaan tugas PPAT yaitu membuat akta dan membuat surat-surat yang diperlukan dalam rangka mendaftarkan perubahan data pertanahan. Oleh karena itu dokumen-dokumen elektronik tersebut di atas tidak boleh digandakan oleh calon PPAT yang sedang magang.

Draf akta PPAT dan draf surat-surat yang tersimpan pada komputer di kantor PPAT berisi uraian identitas penghadap, identitas hak atas tanah, dan perbuatan hukum yang dilakukan. Isi akta dan surat-surat tersebut wajib dirahasiakan oleh PPAT sesuai dengan sumpah jabatan PPAT. Berdasarkan Pasal 34 ayat (1) Peraturan Kepala Badan Pertanahan Nasional Nomor 23 Tahun 2009 tentang Perubahan Atas Peraturan Kepala Badan Pertanahan Nasional Nomor 1 Tahun 2006 tentang Ketentuan Pelaksanaan Peraturan Pemerintah Nomor 37 Tahun 1998 tentang Peraturan Jabatan Pejabat Pembuat Akta Tanah (selanjutnya disingkat Perka BPN tentang Ketentuan Pelaksana Peraturan Jabatan PPAT), salah satu pernyataan sumpah jabatan PPAT adalah bersumpah akan merahasiakan isi akta dan protokol yang tersimpan di kantor PPAT. Menjaga kerahasiaan isi akta bertujuan untuk melindungi kepentingan para pihak pada akta bersangkutan.

Draf akta dan draf surat-surat memang merupakan dokumen yang belum selesai pembuatannya karena belum ditanda tangani, namun di dalam draf akta dan draf surat-surat terkandung isi akta. Isi akta tersebut wajib dirahasiakan oleh PPAT, oleh karena itu calon PPAT yang melaksanakan magang dilarang menggandakan draf akta dan draf surat-surat yang terdapat di kantor PPAT. Apabila diperbolehkan menggandakan, dikhawatirkan hasil penggandaan dokumen tersebut dilihat oleh orang lain kemudian isi akta tersebar ke pihak yang tidak berhak dan digunakan untuk melakukan perbuatan yang merugikan para pihak dalam akta.

\subsubsection{Contoh Dokumen Pelaksanaan Jabatan PPAT}

Pada format surat pernyataan magang yang terdapat pada lampiran Permen ATR/BPN 10/2017 tertulis pernyataan bahwa calon PPAT yang melaksanakan magang berjanji tidak akan menggandakan dokumen pelaksanaan jabatan PPAT dan protokol. Protokol yang tersimpan pada kantor PPAT terdiri dari:

a. Buku daftar akta yaitu catatan mengenai semua akta yang dibuat oleh PPAT selama masa jabatannya yang dibuat secara berurutan menurut waktu pembuatan akta (Pasal 26 Peraturan Jabatan PPAT jo. Pasal 56 Perka BPN tantang Ketentuan Pelaksana Peraturan Jabatan PPAT).

b. Akta asli yaitu setiap rangkap akta PPAT lembar pertama yang wajib dijilid menjadi buku dan disimpan oleh PPAT (Pasal 25 Peraturan Jabatan PPAT). Berdasarkan Pasal 58 ayat (2) Perka BPN tentang Ketentuan Pelaksana Peraturan Jabatan PPAT, 
dokumen-dokumen yang harus dijahit menjadi satu dengan akta asli dan disimpan sebagai protokol PPAT adalah akta atau surat kuasa, persetujuan atau bentuk pemberian kewenangan lain, dan peta atau surat yang menjelaskan obyek perbuatan hukum.

c. Warkah yaitu kumpulan dokumen sebagai dasar pembuatan akta yang wajib dijilid dalam bundel warkah (Pasal 60 Perka BPN tentang Ketentuan Pelaksana Peraturan Jabatan PPAT). Contoh warkah adalah fotokopi kartu tanda penduduk (KTP) penghadap, fotokopi akta pendirian perusahaan, fotokopi sertipikat tanah, dan fotokopi Surat Pemberitahuan Pajak Terhutang (SPPT) Pajak Bumi dan Bangunan (PBB) sebagai dasar kebenaran komparisi penghadap, uraian obyek perbuatan hukum, dan nomor SPPT PBB yang dicantumkan pada akta.

d. Arsip laporan misalnya arsip dari laporan bulanan tentang akta-akta PPAT selama satu bulan yang dikirim oleh PPAT kepada kantor pertanahan dan kantor pajak (Pasal 26 ayat (3) Peraturan Jabatan PPAT jo. Pasal 62 Perka BPN tentang Ketentuan Pelaksana Peraturan Jabatan PPAT).

e. Agenda dan surat-surat yaitu agenda pelaksanaan jabatan PPAT dan surat-surat yang dibuat oleh PPAT untuk keperluan pendaftaran akta dan pelaksanaan jabatannya, misalnya surat pengantar yang menjabarkan daftar dokumen yang diajukan untuk mendaftar hak tanggungan ke kantor pertanahan sebagaimana dimaksud Pasal 114 Permen Agraria 3/1997 dan surat pemberitahuan yang wajib diberikan PPAT kepada para pihak bahwa akta telah didaftarkan ke kantor pertanahan sesuai yang diamanatkan Pasal 40 ayat (2) PP 24/1997.

Dokumen pelaksanaan jabatan PPAT merupakan dokumen-dokumen yang digunakan melaksanakan jabatan PPAT seperti dokumen-dokumen untuk keperluan pengecekan sertipikat, dokumen yang dipersyaratkan untuk pembuatan akta, dan dokumen yang diperlukan untuk mendaftarkan akta ke kantor pertanahan. Berdasarkan Pasal 97 ayat (1) Permen Agraria 3/1997 jo. Pasal 54 ayat (1) Perka BPN tentang Ketentuan Pelaksana Peraturan Jabatan PPAT, PPAT wajib melakukan pengecekan sertipikat ke kantor pertanahan sebelum membuat akta. Pengecekan sertipikat merupakan pemeriksaan kesesuaian data yang tercantum pada sertipikat dengan data pada buku tanah di kantor pertanahan dan memeriksa ada atau tidaknya catatan pada buku tanah tersebut. Pengecekan sertipikat dilakukan untuk memastikan tanah yang akan menjadi obyek akta tidak sedang disengketakan, tidak dijadikan jaminan utang, tidak sedang disita atau diblokir oleh pihak yang berwenang. ${ }^{11}$ Dokumen pelaksanaan jabatan PPAT yang digunakan untuk melakukan pengecekan sertipikat secara elektronik sesuai Pasal 5 ayat (2) dan ayat (4) Permen ATR/BPN 5/2017 adalah berbentuk dokumen elektronik yang terdiri dari:

a. Identitas pemilik sertipikat dan surat kuasa jika pengecekan dilakukan melalui kuasa;

b. Sertipikat asli;

c. Surat pernyataan dari pemilik sertipikat mengenai keaslian sertipikat, bahwa pemilik sertipikat adalah pemegang hak yang sebenarnya, dan bersedia bertanggung jawab atas data yang diakses; dan

d. Surat penugasan atau surat perjanjian kerja dengan instansi berwenang.

11 Putri, C. A., \& Gunarto, G. (2018). Efektivitas Pengecekan Sertifikat Terhadap Pencegahan Sengketa Tanah Dalam Proses Peralihan Hak Atas Tanah. Jurnal Akta, 5(1), 267-274, h. 269. 
Apabila hasil pengecekan sertipikat menunjukkan bahwa data pada sertipikat sesuai dengan data pada kantor pertanahan serta tanah bersih dari pemblokiran dan sita, selanjutnya PPAT memerlukan beberapa dokumen sebagai persyaratan yang harus dipenuhi oleh penghadap. Berdasarkan Pasal 98 jo. Pasal 99 Permen Agraria 3/1997, dokumen-dokumen yang diperlukan PPAT sebelum membuat akta pemindahan hak adalah:

a. Izin pemindahan hak apabila ingin membuat akta pemindahan hak pakai atas tanah negara; dan

b. Surat pernyataan dari calon penerima hak yang menerangkan bahwa tidak memiliki tanah melebihi batas maksimal kepemilikan tanah dan tidak menjadi pemilik tanah absentee.

PPAT membuat dua rangkap akta asli. Satu rangkap disimpan di kantor PPAT dan satu rangkap didaftar ke kantor pertanahan. Pendaftaran wajib dilakukan karena hak kebendaan atas tanah dapat muncul apabila pendaftaran telah dilakukan. Jika belum didaftarkan maka keberadaan hak kebendaan atas tanah hanya berlaku bagi diri pribadi pembeli tanah saja dan belum berlaku bagi masyarakat umum. ${ }^{12}$ Dokumen yang digunakan PPAT untuk melakukan pendaftaran pemindahan hak dan pembebanan hak sesuai Pasal 103 dan Pasal 114 Permen Agraria 3/1997 adalah:

a. Surat pengantar yang menerangkan daftar dokumen yang diajukan ke kantor pertanahan. Surat ini hanya diperlukan untuk mendaftarkan hak tanggungan;

b. Surat permohonan pendaftaran;

c. Surat kuasa mengajukan pendaftaran apabila menggunakan kuasa;

d. Akta PPAT lembar kedua. Khusus untuk mendaftar hak tanggungan disampaikan pula salinan Akta Pemberian Hak Tanggungan (APHT) dan apabila melalui kuasa disampaikan pula Surat Kuasa Membebankan Hak Tanggungan;

e. Fotokopi identitas pihak-pihak dalam akta. Apabila pihak dalam akta adalah badan hukum maka wajib diajukan fotokopi akta pendirian dan keputusan pengesahan badan hukum;

f. Sertipikat hak atas tanah atau apabila belum bersertipikat dapat menggunakan petuk pajak bumi, pipil, girik, atau kekitir sebagaimana dimaksud Pasal 76 Permen Agraria 3/1997;

g. Izin pemindahan hak; dan

h. Bukti pelunasan Bea Perolehan Hak Atas Tanah dan Bangunan serta bukti pelunasan Pajak Penghasilan yang keduanya hanya diajukan untuk pendaftaran pemindahan hak.

Dokumen pelaksanaan jabatan PPAT lainnya selain dokumen-dokumen yang disebutkan di atas adalah draf akta dan draf surat-surat dalam bentuk dokumen elektronik yang tersimpan di komputer serta salinan akta PPAT. Draf akta dan draf surat-surat yang tersimpan pada komputer serta salinan akta bukan merupakan protokol PPAT dan tidak wajib disimpan, walau demikian dokumen-dokumen tersebut termasuk sebagai dokumen pelaksanaan jabatan PPAT karena dalam menjalankan tugasnya PPAT akan membuat draf akta sebelum dicetak dan ditanda tangani oleh penghadap, saksi dan PPAT. Draf akta tersebut dicetak empat rangkap. Dua rangkap sebagai akta asli dan dua rangkap sebagai salinan. Salinan akta tersebut diberikan kepada para pihak. Khusus terhadap salinan APHT wajib diberikan juga ke

12 Usanti, T. P. (2012). Lahirnya Hak Kebendaan. Perspektif, 17(1), 44-53, h. 47. 
kantor pertanahan untuk dijarit pada sertipikat hak tanggungan sebagaimana ditentukan Pasal 114 ayat (1) huruf f Permen Agraria 3/1997. PPAT juga membuat draf surat-surat misalnya surat pengantar yang isinya mengenai daftar surat-surat yang diajukan ke kantor pertanahan untuk keperluan mendaftar hak tanggungan.

\subsection{Larangan Menggandakan Dokumen Pelaksanaan Jabatan PPAT Bagi Peserta Magang}

3.2.1. Pengaturan Larangan Menggandakan Dokumen Berdasarkan Hukum Positif

Larangan menggandakan dokumen yang berlaku khusus bagi calon PPAT yang melakukan magang diatur pada Pasal 9 ayat (3) Permen ATR/BPN 10/2017 yang menentukan "peserta magang dilarang menggandakan dokumen pelaksanaan jabatan PPAT." Permen ATR/BPN 10/2017 hanya mengatur normanya saja tetapi tidak mengatur sanksi yang dapat dijatuhkan kepada pelanggar norma bersangkutan. Hal tersebut dapat menyebabkan ketidakpastian bagi hakim dalam menjatuhkan sanksi karena dalam memberikan sanksi hakim harus berpedoman pada aturan hukum sesuai asas legalitas.

Asas legalitas mempunyai makna bahwa suatu perbuatan tidak boleh digolongkan sebagai perbuatan pidana apabila perbuatan tersebut sebelumnya tidak dilarang dan tidak diancam dengan pidana berdasarkan peraturan yang sudah berlaku. Asas legalitas menghendaki bahwa bukan hanya perbuatannya yang harus sudah diatur dalam hukum positif tetapi sanksinya juga harus sudah diatur. ${ }^{13}$ Berdasarkan teori vom psychologischen zwang atau teori tekanan psikis, adanya sanksi yang telah diatur sebelumnya dapat menjadi upaya preventif untuk mencegah seseorang melakukan perbuatan pidana karena orang tersebut akan menekan batinnya atau niatnya melakukan perbuatan yang dilarang. ${ }^{14}$

Pepatah dalam bahasa latin yang berkaitan dengan asas legalitas menyebutkan nulla poena sine lege, artinya tidak ada sanksi yang dapat dijatuhkan apabila tidak diatur terlebih dahulu dalam peraturan hukum. Konsekuensinya hakim tidak dapat memberi hukuman selain yang telah diatur pada suatu pasal dalam peraturan hukum. ${ }^{15}$ Urgensi adanya ketentuan sanksi pidana yang diancamkan terhadap pelanggaran suatu pasal adalah untuk memberi kepastian hukum dan keadilan bagi para terdakwa. Apabila tidak diatur sanksi atas pelanggaran terhadap pasal tertentu maka dapat saja dua terdakwa yang melanggar pasal yang sama diberikan hukuman yang berbeda karena masing-masing terdakwa diadili pada pengadilan yang berbeda. Apalagi jenis sanksi yang diberikan berbeda-beda, misalnya salah satu terdakwa diberi hukuman penjara sedangkan terdakwa lainnya hanya menerima hukuman denda. Tentu saja ini jauh dari kesan adil.

Permen ATR/BPN 10/2017 tidak menentukan ancaman sanksi bagi peserta magang yang menggandakan dokumen pelaksanaan jabatan PPAT, oleh karena itu perlu dicari

${ }^{13}$ Moeljatno. (2009). Asas-asas Hukum Pidana. Jakarta: Rineka Cipta, h. 27.

${ }^{14}$ Mediawati, N. F. (2017). Eksistensi Asas Legalitas dalam Penegakan Hak Asasi Manusia: Sebuah Kajian Dilematis. Fairness and Justice: Jurnal Ilmiah Ilmu Hukum, 9(17), 41-59, h. 50.

15 Pah, G. G. A., Irianto, E., \& Wulandari, L. (2014). Analisis Yuridis Penjatuhan Pidana Oleh Hakim Dalam Tindak Pidana Korupsi (Putusan Nomor: 2031 K/PID.SUS/2011). Lentera Hukum, 1(1), 33-41, h. 38. 
peraturan-peraturan lain yang dapat diterapkan terhadap pelanggaran tersebut. Setelah ditelusuri, terdapat peraturan yang mengatur larangan dan sanksi yang dapat dijatuhkan kepada pelaku penggandaan dokumen elektronik. Pasal 30 ayat (2) Undang-Undang Nomor 19 Tahun 2016 tentang Perubahan Atas Undang-Undang Nomor 11 Tahun 2008 tentang Informasi dan Transaksi Elektronik (selanjutnya disingkat UU ITE) mengatur "setiap orang dengan sengaja dan tanpa hak atau melawan hukum mengakses komputer dan/atau sistem elektronik dengan cara apa pun dengan tujuan untuk memperoleh informasi elektronik dan/atau dokumen elektronik." Perbuatan mengakses komputer untuk memperoleh dokumen elektronik diancam dengan hukuman tujuh tahun penjara dan denda tujuh ratus juta rupiah sesuai Pasal 46 ayat (2) UU ITE. Unsur-unsur Pasal 30 ayat (2) UU ITE adalah:
a. Sengaja;
b. Tanpa hak atau melawan hukum;
c. Mengakses komputer atau sistem elektronik;
d. Bertujuan memperoleh dokumen elektronik.

Perbuatan menggandakan dokumen elektronik tentu saja bertujuan untuk memperoleh dokumen elektronik. Agar dapat menggandakan dokumen elektronik pasti didahului dengan mengakses komputer atau sistem elektronik. Apabila orang yang menggandakan dokumen elektronik tersebut melakukannya tanpa izin dari orang yang berhak maka dapat dijatuhkan hukuman yang diatur Pasal 46 ayat (2) UU ITE. UU ITE berlaku bagi masyarakat umum termasuk calon PPAT yang sedang menjalani magang, oleh karena itu larangan-larangan dan sanksi yang diatur dapat diterapkan kepadanya.

Menggandakan dokumen elektronik juga dapat dilakukan dengan cara mentransfer dokumen elektronik. Mentransfer dokumen fisik berbeda dengan mentransfer dokumen elektronik. Perbedaannya adalah ketika mentransfer dokumen fisik tidak menyebabkan dokumen fisik tersebut menjadi ganda, sedangkan saat mentransfer dokumen elektronik akan menyebabkan dokumen elektronik menjadi ganda. Mentransfer dokumen elektronik akan menghasilkan dokumen elektronik yang sama ada di dua perangkat yaitu di perangkat semula dan di perangkat yang menerima transfer sehingga terjadi penggandaan dokumen elektronik. Demi menghalangi perbuatan tersebut Pasal 32 ayat (2) UU ITE mengatur larangan "setiap orang dengan sengaja dan tanpa hak atau melawan hukum dengan cara apa pun memindahkan atau mentransfer informasi elektronik dan/atau dokumen elektronik kepada sistem elektronik orang lain yang tidak berhak." Kepada orang yang melanggar akan dihukum sembilan tahun penjara dan denda tiga miliar rupiah sesuai Pasal 48 ayat (2) UU ITE.

UU ITE hanya dapat diberlakukan terhadap perbuatan menggandakan dokumen elektronik. Pelaku penggandaan dokumen fisik tidak dapat dijerat dengan UU ITE sehingga perlu dicari peraturan yang lain. Induk peraturan hukum yang mengatur mengenai larangan melakukan kejahatan dan pelanggaran adalah Kitab UndangUndang Hukum Pidana (KUHP). Larangan menggandakan dokumen diatur pada Pasal 528 ayat (1) angka 1 KUHP yaitu "Dengan hukuman kurungan selama-lamanya dua bulan atau denda sebanyak-banyaknya Rp. 4.500,-, dihukum barang siapa dengan tidak seizin pembesar yang wajib, menyalin atau memetik isi surat-surat jabatan kepunyaan negeri atau badan-badan negeri, sedang pemerintah umum telah 
memerintahkan supaya dirahasiakan." Larangan tersebut tidak berlaku apabila perintah untuk merahasikan surat-surat tersebut bukan berdasarkan kepentingan umum atau kepentingan dinas. Pengecualian tersebut diatur Pasal 528 ayat (2) KUHP. Unsur-unsur Pasal 528 ayat (1) angka 1 KUHP adalah:

a. Tanpa izin pejabat yang berwajib;

b. Menyalin atau memetik surat jabatan milik negeri atau badan-badan negeri;

c. Ada perintah merahasiakan surat tersebut.

Pasal 528 ayat (1) angka 1 KUHP hanya dapat diberlakukan terhadap penggandaan surat-surat jabatan kepunyaan negeri atau badan negeri, sedangkan Pasal 9 ayat (3) Permen ATR/BPN 10/2017 mengatur mengenai penggandaan dokumen PPAT. KUHP tidak menjelaskan ruang lingkup surat jabatan kepunyaan negeri tersebut. Apakah ruang lingkupnya mencakup juga surat-surat jabatan PPAT, hal ini tidak dijelaskan dalam KUHP. KUHP hanya menjelaskan pihak-pihak yang termasuk dalam pengertian pejabat. Pasal 92 KUHP menentukan pihak-pihak yang masuk pengertian pejabat meliputi orang-orang yang terpilih dalam pemilihan berdasarkan aturan hukum, begitu pula orang-orang yang tidak melalui pemilihan menjadi dewan pembuat peraturan perundang-undangan atau perwakilan rakyat yang dibentuk oleh pemerintah, termasuk pula dewan daerah, dan kepala bangsa Indonesia, hakim dan juga pihak yang disepakati untuk menyelesaikan perselisihan, serta angkatan perang. Pada pasal tersebut tidak ada disebutkan PPAT.

Peraturan hukum dibuat oleh manusia, hal itu menyebabkan tidak semua peraturan hukum berisi aturan yang sempurna, pada beberapa peraturan ada saja ditemukan norma yang kurang jelas atau kosong. Ketika hakim menerima perkara yang berkaitan dengan peraturan hukum yang tidak sempurna tersebut, hakim tidak boleh menolak perkara yang diajukan kepadanya dengan alasan tidak ada peraturan yang mengatur atau aturannya tidak jelas. Larangan bagi hakim untuk menolak perkara yang diterimanya tersebut diamanatkan oleh asas rechtsweigering, karena realitanya tidak semua peraturan mengatur secara lengkap selengkap-lengkapnya atau jelas sejelasjelasnya. ${ }^{16}$ Selain itu terdapat pula asas ius curia novit yang artinya hakim dianggap mengetahui semua hukum yang ada. ${ }^{17}$ Hakim yang memeriksa perkara harus memahami nilai-nilai yang hidup atau dianut pada masyarakat setempat sehingga dapat memberi putusan yang memenuhi rasa keadilan dan diterima dengan baik oleh masyarakat. ${ }^{18}$ Sesuai dengan asas-asas tersebut, walaupun Permen ATR/BPN 10/2017 tidak mengatur sanksi apa yang dapat diberikan kepada peserta magang yang melanggar larangan menggandakan dokumen PPAT dan Pasal 528 KUHP tidak dapat diterapkan secara serta merta kepada peserta magang yang melakukan pelanggaran tersebut, hakim sebagai pemberi keadilan tidak boleh menolak perkara ini. Hakim wajib menelaah lebih dalam nilai yang terkandung pada pasal-pasal tersebut serta memadukannya dengan nilai hukum yang berkembang di kehidupan masyarakat.

${ }^{16}$ Butarbutar, E. N. (2011). Kebebasan Hakim Perdata Dalam Penemuan Hukum Dan Antinomi Dalam Penerapannya. Mimbar Hukum-Fakultas Hukum Universitas Gadjah Mada, 23(1), 61-76, h. 65.

17 Kuswarini. (2018). Azas Ius Curia Novit dan Eksistensi Keterangan Ahli Hukum dalam Peradilan Pidana. Hukum dan Dinamika Masyarakat, 16(1), 95-104, h. 96.

18 Tjukup, I. K., Martiana, N. A., Putra, D. N. R. A., Dananjaya, N. S., \& Putra, I. P. R. A. (2015). Penerapan Teori Hukum Pembangunan dalam Mewujudkan Peradilan Sederhana, Cepat dan Biaya Murah. Jurnal Hukum Acara Perdata ADHAPER, 1(1), 146-160, h. 157. 
Pasal-pasal dalam KUHP tidak boleh diterapkan menggunakan teknik analogi, tetapi masih dapat diterima penerapan hukum pidana melalui penafsiran secara ekstensif. Penafsiran ekstensif merupakan penafsiran yang memperluas suatu ketentuan dalam peraturan hukum dengan jalan mencari maksud pembentuk peraturan. Hasil dari penafsiran ekstensif memang memperluas ketentuan peraturan hukum tetapi tetap bepatokan pada jiwa peraturan tersebut. ${ }^{19}$ Pada penafsiran ekstensif, pengertian kata atau frasa yang kurang jelas pada ketentuan hukum diberi makna sesuai dengan pemahaman masyarakat terhadap frasa tersebut pada masa sekarang sehingga makna frasa tersebut menjadi lebih luas dibandingkan dengan pada saat undang-undang dibuat, namun hakim tetap berpegang pada tujuan peraturan tersebut. ${ }^{20}$

Perbuatan menggandakan dokumen PPAT tanpa izin jelas-jelas merupakan perbuatan tidak terpuji baik ditinjau dari hukum positif maupun norma-norma sosial yang berlaku di masyarakat. Orang yang melanggarnya harus diberi hukuman yang sepadan, namun Permen ATR/BPN 10/2017 tidak mengatur jenis dan berat-ringannya hukuman yang dapat diberikan. Bagi pelaku penggandaan dokumen jabatan PPAT yang berbentuk dokumen elektronik dapat diberi sanksi sesuai UU ITE, tetapi kepada pelaku penggandaan dokumen jabatan PPAT yang berbentuk dokumen fisik/dokumen tercetak tidak ditemukan peraturan yang jelas-jelas mengatur tentang sanksinya. Pasal 528 KUHP mengatur sanksi bagi pelaku penggandaan dokumendokumen jabatan milik negeri atau badan negeri. PPAT bukanlah pegawai negeri dan berdasarkan Pasal 7 Peraturan Jabatan PPAT, orang yang berkedudukan sebagai PPAT dilarang merangkap profesi sebagai pegawai negeri, oleh karenanya sanksi pada Pasal 528 KUHP tidak dapat diterapkan secara serta merta kepada pelaku penggandaan dokumen jabatan PPAT. Hakim perlu melakukan penafsiran terhadap frasa "surat jabatan milik negeri" dalam Pasal 528 KUHP untuk menentukan dokumen jabatan PPAT termasuk dalam ruang lingkupnya atau tidak.

Metode penafsiran yang tepat digunakan untuk menemukan sanksi yang pantas dijatuhkan kepada pelaku penggandaan dokumen jabatan PPAT adalah penafsiran ekstensif. Penafsiran ekstensif digunakan untuk menafsirkan frasa "surat jabatan milik negeri" pada Pasal 528 ayat (1) angka 1 KUHP sesuai dengan pemahaman masyarakat pada saat ini dengan tetap berpatokan pada maksud atau tujuan dirumuskannya Pasal 528 KUHP. Pengertian frasa "surat jabatan milik negeri" ditafsirkan berdasarkan makna frasa tersebut pada masa sekarang ruang lingkupnya meliputi pula dokumen jabatan PPAT karena PPAT merupakan pejabat umum yang dilantik oleh pejabat negara yaitu Menteri Agraria sebagaimana ketentuan Pasal 1 dan Pasal 5 Peraturan Jabatan PPAT. Tugas yang diberikan kepada PPAT juga termasuk dalam tugas pemerintah dalam hal menyelenggarakan pendaftaran tanah. Pasal 5 dan Pasal 6 PP 24/1997 jo. Pasal 2 Peraturan Jabatan PPAT menjelaskan BPN bertanggung jawab menyelenggarakan pendaftaran tanah dan dalam melaksanakan kegiatannya tersebut BPN dibantu oleh PPAT, dengan demikian sudah jelas PPAT adalah pejabat umum yang membantu negara dalam kegiatan pendaftaran tanah. Tujuan Pasal 528 KUHP adalah untuk melarang dan menghukum orang-orang yang menggandakan dokumendokumen milik pejabat yang sifatnya rahasia. Poin pentingnya adalah dokumen

19 Christianto, H. (2010). Batasan dan Perkembangan Penafsiran Ekstensif dalam Hukum

Pidana. Pamator Journal, 3(2), 101-113, h. 103.

${ }^{20}$ Moeljatno, op.cit, h. 31. 
tersebut bersifat rahasia sehingga tidak boleh digandakan oleh orang-orang yang tidak berhak tanpa izin. Dokumen-dokumen jabatan PPAT seperti akta dan warkah-warkah akta, isinya bersifat rahasia dan tidak boleh diketahui oleh orang yang tidak berhak sesuai Pasal 34 ayat (1) Perka BPN tentang Ketentuan Pelaksana Peraturan Jabatan PPAT. Jadi yang dimaksud dengan surat jabatan milik negeri termasuk pula dokumen jabatan PPAT sehingga sanksi yang tercantum pada Pasal 528 KUHP dapat ditarapkan pula kepada peserta magang yang menggandakan dokumen jabatan PPAT.

\subsubsection{Penggandaan Dokumen Jabatan PPAT Oleh Peserta Magang Atas Permintaan PPAT}

PPAT perlu memfotokopi berbagai dokumen dalam melaksanakan jabatannya. Misalnya memfotokopi KTP penghadap beserta akta pendirian perusahaan dalam hal penghadap merupakan rechtpersoon. Fotokopi dokumen tersebut digunakan sebagai dokumen pelengkap untuk mendaftarkan akta ke kantor pertanahan. Bukan hanya untuk keperluan pendaftaran akta, PPAT memfotokopi dokumen juga untuk melaksanakan kewajibannya menyimpan dokumen-dokumen yang merupakan dasar pembuatan akta sebagai protokol PPAT. Tugas PPAT bukan hanya memfotokopi dokumen, masih banyak pekerjaan lain yang harus dilakukan PPAT, misalnya membuat akta, mendaftarkan akta, menulis buku daftar akta, mengirim laporan tentang akta-akta yang dibuat, menjilid minuta akta, dan menjilid warkah. Saking banyaknya tugas yang harus dikerjakan, PPAT meminta bantuan kepada pegawai dan calon PPAT yang sedang dalam tahap magang di kantor PPAT.

Pasal 9 ayat (3) Permen ATR/BPN 10/2017 melarang calon PPAT yang sedang magang menggandakan dokumen pelaksanaan jabatan PPAT. Pada kenyataannya ketika menjalani magang peserta magang biasanya dimintai bantuan oleh PPAT untuk memfotokopi atau menggandakan dokumen jabatan PPAT karena diperlukan untuk didaftarkan bersama dengan akta PPAT ke kantor pertanahan dan untuk disimpan menjadi protokol. Peserta magang melakukannya semata-mata untuk membantu PPAT dan karena dimintai tolong oleh PPAT.

Pasal 50 KUHP menganut prinsip bahwa tidak boleh menjatuhkan hukuman kepada orang yang malakukan perbuatan untuk melaksanakan ketentuan peraturan hukum. Calon PPAT yang dalam tahap magang mempunyai kewajiban yang ditentukan Pasal 9 ayat (2) Permen ATR/BPN 10/2017 untuk membantu PPAT dalam membuat akta dan melaksanakan penatausahaan dan pengelolaan protokol PPAT. Kegiatan penatausahaan dan pengelolaan protokol PPAT merupakan kegiatan menulis catatan tentang akta-akta yang dibuat PPAT pada buku daftar akta dan membuat arsip dokumen-dokumen yang menjadi dasar pembuatan akta (warkah akta) untuk disimpan sebagai protokol. Warkah akta tersebut dapat berupa dokumen asli maupun fotokopi sesuai dengan yang tersedia di kantor PPAT. Jika calon PPAT yang sedang magang memfotokopi atau menggandakan dokumen jabatan PPAT atas izin dari PPAT untuk membuat arsip warkah-warkah akta lalu disimpan sebagai protokol maka perbuatan tersebut bukan pelanggaran. Alasan pembenar pada Pasal 50 KUHP telah menghapuskan sifat melawan hukum perbuatan tersebut karena penggandaan dokumen dilakukan untuk memenuhi kewajiban yang ditentukan Pasal 9 ayat (2) Permen ATR/BPN 10/2017. 
Alasan pembenar hanya berlaku terhadap tindakan menggandakan dokumen jabatan PPAT yang dilakukan untuk menyiapkan arsip protokol PPAT. Perbuatan menggandakan dokumen jabatan PPAT untuk keperluan lainnya, misalnya untuk mempersiapkan dokumen-dokumen yang akan didaftarkan ke kantor pertanahan, tetap merupakan perbuatan melanggar hukum. Unsur-unsur Pasal 9 ayat (3) Permen ATR/BPN 10/2017 adalah:

a. Peserta magang;

b. Menggandakan dokumen pelaksanaan jabatan PPAT.

Pada pasal tersebut tidak terdapat unsur "tanpa izin", dengan demikian dapat diartikan bahwa walaupun peserta magang menggandakan dokumen jabatan PPAT setelah memperoleh izin dari PPAT, peserta magang tetap melanggar Pasal 9 ayat (3) Permen ATR/BPN 10/2017. Di sisi lain, tidak adanya unsur "tanpa izin" menimbulkan keragu-raguan bagi peserta magang untuk membantu PPAT memfotokopi dokumen-dokumen jabatan PPAT. Keragu-raguan tersebut timbul karena Pasal 9 ayat (3) Permen ATR/BPN 10/2017 tidak mengatur dengan jelas larangannya hanya berlaku terhadap penggandaan dokumen tanpa izin atau berlaku juga terhadap penggandaan dokumen yang dilakukan atas izin dari PPAT.

Ketidakjelasan norma di atas dapat diatasi dengan melakukan interpretasi sistematis. Interpretasi sistematis adalah menginterpretasi ketentuan pasal dengan cara menghubungkan ketentuan pasal tersebut dengan keseluruhan pasal pada paraturan yang bersangkutan dan/atau dihubungkan dengan pasal-pasal pada peraturanperaturan lain yang mengatur hal yang sama. ${ }^{21}$ Peraturan hukum yang satu dengan peraturan yang lainnya merupakan satu kesatuan sistem. Menafsirkan suatu ketentuan dalam peraturan hukum tidak boleh menyimpang atau harus disesuaikan dengan peraturan-peraturan lainnya karena seluruh peraturan merupakan kesatuan sistem. ${ }^{22}$

Peraturan hukum lain yang mengatur larangan menggandakan dokumen adalah Pasal 528 KUHP, Pasal 30 ayat (2) dan Pasal 32 ayat (2) UU ITE. Pasal 528 KUHP mengandung unsur "tanpa izin". Pasal 30 ayat (2) dan Pasal 32 ayat (2) UU ITE berisi unsur "tanpa hak". Pasal 9 ayat (3) Permen ATR/BPN 10/2017 harus ditafsirkan dengan mengaitkannya dengan larangan serupa yang diatur pada peraturan lainnya, dengan demikian dapat ditafsirkan bahwa larangan yang diatur Pasal 9 ayat (3) Permen ATR/BPN 10/2017 adalah larangan menggandakan dokumen jabatan PPAT yang dilakukan tanpa hak atau tanpa izin dari PPAT.

Hukum pidana mengenal ajaran sifat melawan hukum materiil dalam fungsi yang negatif, yaitu menghilangkan sifat melawan hukum suatu perbuatan yang telah memenuhi seluruh unsur perbuatan pidana yang diatur pada peraturan hukum, karena berdasarkan norma yang hidup dalam masyarakat perbuatan tersebut dianggap baik dan tidak tercela sehingga orang yang melakukannya tidak dihukum. ${ }^{23}$ Yurisprudensi menentukan bahwa ada tiga kriteria pemberlakuan fungsi negatif dari sifat melawan hukum materiil, yaitu tidak merugikan negara, melayani kepentingan

${ }^{21}$ Wibowo, M. (2015). Menakar Konstitusionalitas Sebuah Kebijakan Hukum Terbuka Dalam Pengujian Undang-Undang. Jurnal Konstitusi, 12(2), 196-216, h. 202.

22 Syaputra, M. Y. A. (2017). Penafsiran Hukum oleh Hakim Mahkamah Konstitusi. Jurnal Mercatoria, 1(2), 115-129, h. 120.

${ }^{23}$ Moeljatno. op.cit, h. 144. 
umum, dan pelaku tidak mendapat keuntungan. Selain itu, yurisprudensi juga menentukan bahwa asas-asas keadilan dan asas hukum tidak tertulis dapat dijadikan pertimbangan menghilangkan sifat melawan hukum suatu perbuatan. ${ }^{24}$

Tindakan peserta magang menggandakan dokumen jabatan PPAT atas permintaan PPAT untuk membantu menyiapkan berkas-berkas pelengkap pendaftaran akta sudah jelas tidak menimbulkan kerugian bagi negara dan juga tidak dilakukan untuk mendapatkan keuntungan. Peserta magang dapat saja memperoleh keuntungan tetapi keuntungannya hanya berupa memperoleh pengalaman dan ilmu mengenai berkasberkas yang harus disiapkan. Peserta magang sama sekali tidak mendapat keuntungan ekonomis. Perbuatan tersebut justru bersifat melayani atau membantu PPAT melaksanakan tugas-tugasnya. Ditinjau dari segi norma yang berlaku di masyarakat perbuatan tersebut sama sekali tidak tercela karena dilakukan atas seizin PPAT, bahkan perbuatan tersebut merupakan perilaku terpuji karena membantu PPAT sehingga dapat lebih efisien waktu.

Berdasarkan penjelasan di atas, Pasal 9 ayat (3) Permen ATR/BPN 10/2017 harus dimaknai bahwa larangan menggandakan dokumen jabatan PPAT hanya berlaku apabila tidak memperoleh izin dari PPAT dan dilakukan untuk kepentingan lain selain pelaksanaan jabatan PPAT. Penggandaan dokumen untuk keperluan lain diluar pelaksanaan jabatan PPAT berpotensi menyebabkan isi akta atau protokol yang sifatnya rahasia menjadi tersebar ke pihak yang tidak berhak. Apabila isi akta tersebar luas ke publik maka dapat merugikan para pihak yang melakukan perbuatan hukum pada akta dan pihak lainnya yang terkait, oleh karena itu kerahasiaan isi akta wajib dijaga sebagai upaya melindungi kepentingan pihak-pihak dalam akta. ${ }^{25}$

\section{Kesimpulan}

Ruang lingkup dokumen pelaksanaan jabatan PPAT yang dilarang digandakan oleh calon PPAT yang menjalani magang meliputi dokumen fisik dan dokumen elektronik yang digunakan PPAT melaksanakan seluruh tugas jabatannya. Contohnya adalah protokol PPAT, dokumen-dokumen yang digunakan PPAT untuk mendaftarkan akta ke kantor pertanahan, salinan akta, draf akta dan draf surat-surat yang belum ditanda tangani. Berdasarkan interpretasi sistematis, dengan menghubungkan isi Pasal 9 ayat (3) Permen ATR/BPN 10/2017 dengan pasal-pasal pada peraturan hukum lain yang sama-sama mengatur mengenai larangan penggandaan dokumen, larangan tersebut hanya berlaku terhadap tindakan menggandakan dokumen tanpa izin atau tanpa hak. Didukung pula dengan ajaran sifat melawan hukum materiil dengan fungsi yang negatif bahwa perbuatan peserta magang menggandakan dokumen pelaksanaan jabatan PPAT atas permintaan atau atas seizin PPAT untuk keperluan kantor PPAT bukan merupakan perbuatan yang tercela dari segi norma kehidupan masyarakat sehingga bukan merupakan pelanggaran hukum.

Menteri Agraria hendaknya menambahkan unsur menggandakan tanpa izin PPAT dan unsur menggandakan untuk digunakan selain melaksanakan jabatan PPAT pada

24 Gerungan, L. K. F. R. (2011). Dimensi dan Implementasi "Perbuatan Melawan Hukum Materiil" dalam Tindak Pidana Korupsi pada Putusan Mahkamah Agung Pasca Putusan Mahkamah Konstitusi. Jurnal Hukum Unsrat, 19(5), 60-74, h. 63.

25 Yuliani, R. (2018). Tanggung Jawab Hukum Calon Notaris yang Sedang Magang Terhadap Kerahasiaan Akta. Jurnal Hukum Jatiswara, 33(2), 1-16, h. 10. 
Pasal 9 ayat (3) Permen ATR/BPN 10/2017 agar adanya kejelasan bahwa perbuatan yang dilarang adalah menggandakan dokumen tanpa izin atau menggandakan dokumen untuk digunakan selain melaksanakan jabatan PPAT. Perlu juga diatur sanksinya agar ada kepastian hukum bagi hakim dan pelaku pelanggaran mengenai hukuman yang dapat diberikan.

\section{Daftar Pustaka}

Buku

Mertokusumo, S. (2009). Penemuan Hukum: Sebuah Pengantar. Yogyakarta: Liberty.

Moeljatno. (2009). Asas-asas Hukum Pidana. Jakarta: Rineka Cipta.

Nurita, R. A. E. (2012). Cyber Notary: Pemahaman Awal dalam Konsep Pemikiran. Bandung: PT Refika Aditama.

Salim HS. (2016). Teknik Pembuatan Akta Pejabat Pembuat Akta Tanah (PPAT). Jakarta: Rajawali Pers.

\section{Jurnal}

Butarbutar, E. N. (2011). Kebebasan Hakim Perdata Dalam Penemuan Hukum Dan Antinomi Dalam Penerapannya. Mimbar Hukum-Fakultas Hukum Universitas Gadjah Mada, 23(1), 61-76.

Christianto, H. (2010). Batasan dan Perkembangan Penafsiran Ekstensif dalam Hukum Pidana. Pamator Journal, 3(2), 101-113.

Gerungan, L. K. F. R. (2011). Dimensi dan Implementasi “Perbuatan Melawan Hukum Materiil" dalam Tindak Pidana Korupsi pada Putusan Mahkamah Agung Pasca Putusan Mahkamah Konstitusi. Jurnal Hukum Unsrat, 19(5), 60-74.

Kuswarini. (2018). Azas Ius Curia Novit dan Eksistensi Keterangan Ahli Hukum dalam Peradilan Pidana. Hukum dan Dinamika Masyarakat, 16(1), 95-104.

Mediawati, N. F. (2017). Eksistensi Asas Legalitas dalam Penegakan Hak Asasi Manusia: Sebuah Kajian Dilematis. Fairness and Justice: Jurnal Ilmiah Ilmu Hukum, 9(17), 41-59.

Nabila, S. (2015). Implikasi Yuridis Calon Notaris Magang Yang Tidak Melaksanakan Kewajibannya Sebagaimana Diatur Dalam Pasal 16 a Undang-undang Nomor 2 Tahun 2014 Tentang Jabatan Notaris. Kumpulan Jurnal Mahasiswa Fakultas Hukum.

Nurudin. (2016). Urgensi Penetapan Limitasi Waktu Pemeriksaan Kesesuaian Sertipikat Hak Atas Tanah di Kantor Pertanahan Sebelum Pembuatan Akta Oleh PPAT. Kumpulan Jurnal Mahasiswa Fakultas Hukum.

Pah, G. G. A., Irianto, E., \& Wulandari, L. (2014). Analisis Yuridis Penjatuhan Pidana Oleh Hakim Dalam Tindak Pidana Korupsi (Putusan Nomor: 2031 K/PID.SUS/2011). Lentera Hukum, 1(1), 33-41.

Putri, C. A., \& Gunarto, G. (2018). Efektivitas Pengecekan Sertifikat Terhadap Pencegahan Sengketa Tanah Dalam Proses Peralihan Hak Atas Tanah. Jurnal Akta, 5(1), 267-274. 
Rifauddin, M. (2016). Pengelolaan Arsip Elektronik Berbasis Teknologi. Khizanah AlHikmah Jurnal Ilmu Perpustakaan, Informasi, dan Kearsipan, 4(2), 168-178.

Rismayanthi, I. A. W. (2016). Tanggung Jawab Pejabat Pembuat Akta Tanah (PPAT) terhadap Pendaftaran Peralihan Hak Atas Tanah yang Menjadi Objek Sengketa. Acta Comitas, 1, 77-93.

Swandewi, N. L. P., Murni, R. A. R., \& Dharmawan, N. K. S. (2016). Penggunaan Blanko Akta Pejabat Pembuat Akta Tanah Dengan Diterbitkannya Peraturan Kepala Badan Pertanahan Nasional Nomor 8 Tahun 2012. Acta Comitas, 1, 42-51.

Syaputra, M. Y. A. (2017). Penafsiran Hukum oleh Hakim Mahkamah Konstitusi. Jurnal Mercatoria, 1(2), 115-129.

Tjukup, I. K., Martiana, N. A., Putra, D. N. R. A., Dananjaya, N. S., \& Putra, I. P. R. A. (2015). Penerapan Teori Hukum Pembangunan dalam Mewujudkan Peradilan Sederhana, Cepat dan Biaya Murah. Jurnal Hukum Acara Perdata ADHAPER, 1(1), 146-160.

Usanti, T. P. (2012). Lahirnya Hak Kebendaan. Perspektif, 17(1), 44-53.

Wibowo, M. (2015). Menakar Konstitusionalitas Sebuah Kebijakan Hukum Terbuka Dalam Pengujian Undang-Undang. Jurnal Konstitusi, 12(2), 196-216.

Yuliani, R. (2018). Tanggung Jawab Hukum Calon Notaris yang Sedang Magang Terhadap Kerahasiaan Akta. Jurnal Hukum Jatiswara, 33(2), 1-16.

Yunarko, B. (2013). Kedudukan Jabatan dan Akta Pejabat Pembuat Akta Tanah dalam Sengketa di Peradilan Tata Usaha Negara. Perspektif, 18(3), 188-194.

\section{Tesis/Desertasi}

Saputra, F. H. (2018). Kewajiban Magang Calon Pejabat Pembuat Akta Tanah (PPAT) di Kantor Agraria dan Tata Ruang/Pertanahan Kota Yogyakarta. Universitas Gadjah Mada.

\section{Peraturan Perundang-Undangan}

Undang-Undang Nomor 19 Tahun 2016 tentang Perubahan Atas Undang-Undang Nomor 11 Tahun 2008 tentang Informasi dan Transaksi Elektronik (Lembaran Negara Republik Indonesia Tahun 2016 Nomor 251, Tambahan Lembaran Negara Republik Indonesia Nomor 5952).

Peraturan Pemerintah Nomor 24 Tahun 1997 tentang Pendaftaran Tanah (Lembaran Negara Republik Indonesia Tahun 1997 Nomor 59, Tambahan Lembaran Negara Republik Indonesia Nomor 3696).

Peraturan Pemerintah Nomor 37 Tahun 1998 tentang Peraturan Jabatan Pejabat Pembuat Akta Tanah (Lembaran Negara Republik Indonesia Tahun 1998 Nomor 52, Tambahan Lembaran Negara Republik Indonesia Nomor 3746).

Peraturan Pemerintah Nomor 24 Tahun 2016 tentang Perubahan Atas Peraturan Pemerintah Nomor 37 Tahun 1998 tentang Peraturan Jabatan Pejabat Pembuat Akta Tanah (Lembaran Negara Republik Indonesia Tahun 2016 Nomor 120, Tambahan Lembaran Negara Republik Indonesia Nomor 5893). 
Peraturan Menteri Negara Agraria/Kepala Badan Pertanahan Nasional Nomor 3 Tahun 1997 tentang Ketentuan Pelaksanaan Peraturan Pemerintah Nomor 24 Tahun 1997 tentang Pendaftaran Tanah.

Peraturan Kepala Badan Pertanahan Nasional Nomor 23 Tahun 2009 tentang Perubahan Atas Peraturan Kepala Badan Pertanahan Nasional Nomor 1 Tahun 2006 tentang Ketentuan Pelaksanaan Peraturan Pemerintah Nomor 37 Tahun 1998 tentang Peraturan Jabatan Pejabat Pembuat Akta Tanah.

Peratuan Kepala Badan Pertanahan Nasional Nomor 8 Tahun 2012 tentang Perubahan Atas Peraturan Menteri Negara Agraria/Kepala Badan Pertanahan Nasional Nomor 3 Tahun 1997 tentang Ketentuan Pelaksanaan Peraturan Pemerintah Nomor 24 Tahun 1997 tentang Pendaftaran Tanah.

Peraturan Menteri Agraria dan Tata Ruang/Kepala Badan Pertanahan Nasional Nomor 5 Tahun 2017 tentang Layanan Informasi Pertanahan Secara Elektronik (Berita Negara Republik Indonesia Tahun 2017 Nomor 612).

Peraturan Menteri Agraria dan Tata Ruang/Kepala Badan Pertanahan Nasional Nomor 10 Tahun 2017 tentang Tata Cara Ujian, Magang, Pengangkatan dan Perpanjangan Masa Jabatan Pejabat Pembuat Akta Tanah (Berita Negara Republik Indonesia Tahun 2017 Nomor 967). 